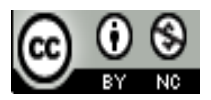

Jurnal Ilmu Pendidikan Fisika is licensed under

A Creative Commons Attribution-Non Commercial 4.0 International License.

\title{
IDENTIFIKASI MiskonSEPSI BUKU AJAR FISIKA SMA KELAS X PADA POKOK BAHASAN KINEMATIKA GERAK LURUS
}

\author{
Hasan Khoiri ${ }^{1)}$, Andika Kusuma Wijaya ${ }^{2)}$, Intan Kusumawati ${ }^{3)}$ \\ 1) STKIP Singkawang, Kota Singkawang, Indonesia \\ E-mail: khoiri_hasan@yahoo.com \\ 2) STKIP Singkawang, Kota Singkawang, Indonesia \\ E-mail: andikakusumawijaya1988@gmail.com \\ 2) STKIP Singkawang, Kota Singkawang, Indonesia \\ E-mail: intankusumawati10@gmail.com
}

\begin{abstract}
Abstrak. Penelitian ini bertujuan untuk memaparkan bentuk-bentuk miskonsepsi pada buku ajar fisika SMA kelas X. Buku ajar dalam penelitian ini, yaitu: (1) Fisika untuk SMA/MA Kelas X Semester I karangan Rinawan Abadi dan Syarifah Isnaini diterbitkan tahun 2012 oleh penerbit Intan Pariwara, (2) Fisika untuk SMA/MA Kelas X Semester I karangan Supiyanto diterbitkan tahun 2007 oleh penerbit Phibeta Aneka Gama, dan (3) Fisika untuk SMA/MA Kelas X karangan Kamajaya diterbitkan tahun 2012 oleh penerbit Grafindo Media Pratama. Berdasarkan analisis data yang telah dilakukan, pada buku ajar Intan Pariwara mengalami miskonsepsi pada aspek penjelasan konsep dengan persentase $20 \%$, penulisan rumus dengan persentase $66,67 \%$, penulisan simbol dengan persentase 40\%, dan penyajian gambar dengan persentase 20\%. Buku ajar Phibeta Aneka Gama mengalami miskonsepsi pada aspek penjelasan konsep dengan persentase $10 \%$, penulisan rumus dengan persentase $22,22 \%$, penulisan simbol dengan persentase $10 \%$, dan penyajian gambar dengan persentase 20\%. Buku ajar Grafindo Media Pratama mengalami miskonsepsi pada aspek penjelasan konsep dengan persentase $20 \%$, penulisan rumus dengan persentase $44,44 \%$, penulisan simbol dengan persentase $10 \%$, dan tidak mengalami miskonsepsi pada aspek penyajian gambar. Pada aspek penulisan satuan, tidak terdapat miskonsepsi pada buku ajar Intan Pariwara, Phibeta Aneka Gama, dan Grafindo Media Pratama. Dari kesimpulan hasil penelitian yang dilakukan, memberikan informasi kepada seluruh guru khususnya pada bidang studi fisika kelas X untuk lebih berhati-hati dalam memilih buku yang digunakan dalam proses pembelajaran di kelas. Penelitian ini sebaiknya dapat dijadikan masukkan bagi penerbit dan dinas pendidikan untuk pembaruan isi dari bahan ajar pada buku tersebut.
\end{abstract}

Kata Kunci: Miskonsepsi; Buku Ajar Fisika SMA; Kinematika Gerak Lurus

\section{PENDAhUluan}

Pendidikan adalah hal yang penting dalam kehidupan manusia. Dengan pendidikan, manusia menjadi lebih berwibawa dan mempunyai pekerjaan serta dapat berakhlak sesuai dengan norma-norma yang ada di masyarakat pada umumnya. Pendidikan dapat menjadi wahana bagi negara untuk membangun Sumber Daya Manusia (SDM) yang diperlukan dalam pembangunan dan juga bagi setiap peserta didik untuk dapat mengembangkan diri sesuai dengan potensi yang dimiliki [1].

Buku ajar merupakan komponen pendidikan yang sangat penting di dalam proses pembelajaran. Tidak dapat dipungkiri semua guru di setiap tingkat pendidikan menggunakan lebih dari satu buku ajar dalam proses pembelajarannya. Kebanyakan guru menggunakan bukulebih dari satu buku ajar dalam proses pembelajarannya. di kelas maupun untuk memberi tugas. Buku ajar digunakan untuk menyampaikan materi dan bahkan menentukan strategi pembelajarannya, sedangkan siswa menggunakan buku ajar sebagai sumber informasi untuk mengerjakan tugas di sekolah dan pekerjaan di rumah [2].

Keberadaan berbagai jenis buku ajar ini tetap mengharuskan seorang guru untuk berpikir kritis dan selektif dalam memilih buku ajar yang sesuai pada Standar Kompetensi (SK) dan Kompetensi Dasar (KD) yang ingin dicapai dan isinya tidak mengandung miskonsepsi [3].

Miskonsepsi adalah suatu konsepsi yang tidak sesuai dengan konsepsi yang diakui oleh para ahli [4]. Miskonsepsi dapat berasal dari buku ajar yang digunakan oleh tenaga pendidiknya maupun anak didiknya tersebut. Faktor utama penyebab dari miskonsepsi fisika, yaitu berasal dari siswa, pengajar, buku ajar, konteks, dan cara mengajar [4]. 


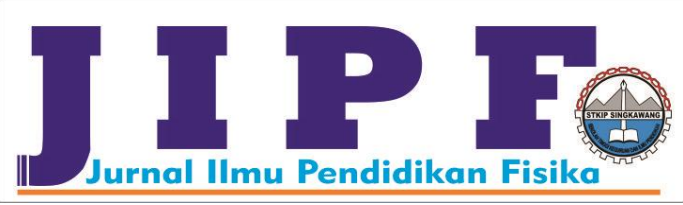

Berdasarkan kelima penyebab miskonsepsi tersebut, Dikmanli \& Cardak (2004) menyimpulkan bahwa miskonsepsi Siswa Menengah Atas (SMA) sebagian besar disebabkan oleh buku ajar [5].

Berdasarkan latar belakang tersebut, maka dilakukan penelitian yang berjudul "Identifikasi Miskonsepsi Buku Ajar Fisika SMA Kelas X pada Pokok Bahasan Kinematika Gerak Lurus". Dengan demikian, penelitian ini diharapkan dapat meminimalisir terjadinya miskonsepsi yang berasal dari buku ajar yang digunakan dalam pembelajaran.

Fisika merupakan satu di antara cabang IPA yang mendasari perkembangan teknologi maju dan konsep hidup harmonis dengan alam [6]. Fisika merupakan ilmu fundamental yang menjadi dasar perkembangan ilmu pengetahuan dan teknologi [7]. Dari kedua rujukan tersebut, dapat disimpulkan bahwa peran dari fisika adalah sangat penting, sebab menjadi dasar pengembangan ilmu yang berkaitan dengan kemajuan pengetahuan dan teknologi.

Pembelajaran fisika dimulai dengan mekanika, yaitu pelajaran yang berhubungan dengan gaya, bahan dan gerak. Bagian dari mekanika yang menerangkan tentang gerak disebut kinematika. Berikutnya dipelajari tentang dinamika, yaitu hubungan antara gerak dan penyebabnya [8]. Perlu dibedakan antara jarak yang telah ditempuh suatu benda, dan perpindahannya, yang didefinisikan sebagai perubahan posisi benda tersebut. Dengan demikian, perpindahan adalah seberapa jauh jarak benda tersebut dari titik awalnya [9].

Aspek yang paling nyata dari gerak benda adalah seberapa cepat benda tersebut bergerak-laju atau kecepatannya. Istilah kecepatan dan laju cenderung dipertukarkan dalam bahasa sehari-hari. Tetapi dalam fisika dibuat perbedaan di antara keduanya. Laju adalah sebuah bilangan positif, dengan satuan $\mathrm{m} / \mathrm{s}$. Kecepatan, dipihak lain, digunakan untuk menyatakan baik besar (nilai numerik) mengenai seberapa cepat sebuah benda bergerak maupun arah geraknya [9]. Penulis [10] menunjukkan, sebenarnya beberapa besaran dihubungkan dengan ungkapan "seberapa cepat". Satu di antaranya adalah kecepatan rata-rata $\overrightarrow{\bar{v}}$, yang merupakan perbandingan perpindahan $\Delta \vec{x}$ yang terjadi selama interval waktu tertentu $\Delta t$ terhadap interval itu yang ditunjukkan pada persamaan (2.1) sebagai berikut.

$$
\overrightarrow{\bar{v}}=\frac{\Delta \bar{x}}{\Delta t}=\frac{\bar{x}_{2}-\bar{x}_{1}}{t_{2}-t_{1}}
$$

Suatu Kelajuan rata-rata $(\bar{s})$ merupakan cara lain untuk mendeskripsikan "seberapa cepat" suatu partikel bergerak. Sementara kecepatan rata-rata melibatkan perpindahan partikel $\Delta \vec{x}$, kelajuan rata-rata melibatkan jarak total yang ditempuh misalnya, jumlah meter perjalanan), tidak bergantung dengan arah [10]. Kecepatan sesaat adalah limit rasio $\Delta \vec{x} / \Delta t$ jika $\Delta t$ mendekati nol. $\lim _{\Delta t \rightarrow 0} \frac{\Delta \vec{x}}{\Delta t}=$ kemiringan garis yang menyinggung kurva $x$ terhadap $t$. $\Delta t \rightarrow 0 \Delta t$

Limit ini dinamakan turunan $x$ terhadap $t$. Dalam notasi kalkulus turunan biasa di tulis $d x / d t[11]$.

$$
\lim _{\Delta t \rightarrow 0} \frac{\Delta \vec{x}}{\Delta t}=\frac{d x}{d t}
$$

Kemiringan ini dapat positif ( $x$ bertambah) atau negatif $(x$ berkurang); dengan demikian, dalam gerakan satu dimensi, kecepatan sesaat mungkin bernilai positif maupun negatif. Besarnya kecepatan sesaat dinamakan kelajuan sesaat [11]. Penulis [8] menunjukkan, ketika kecepatan dari benda yang bergerak berubah terhadap waktu, dikatakan bahwa benda tersebut mempunyai percepatan. Sama halnya seperti kecepatan menggambarkan laju perubahan kecepatan terhadap waktu. Seperti kecepatan, percepatan adalah besaran vektor. Gerak lurus beraturan adalah gerak benda titik yang membuat lintasan berbentuk garis lurus dengan sifat bahwa jarak yang di tempuh tiap satu satuan waktu tetap, baik besar maupun arahnya [12].

Gerak lurus berubah beraturan (GLBB) adalah gerak benda titik yang membuat lintasan berbentuk garis lurus dengan sifat bahwa jarak yang ditempuh tiap satu satuan waktu tidak sama besar, sedang arah gerak tetap [12]. Jarak merupakan panjang lintasan sesungguhnya yang ditempuh oleh suatu benda dalam waktu tertentu. Adapun perpindahan merupakan perubahan kedudukan suatu benda dalam waktu tertentu. Jarak tidak bergantung pada arah sehingga termasuk besaran skalar. Oleh karena itu, jarak selalu bernilai positif Perpindahan bergantung pada arah sehingga perpindahan termasuk besaran vektor [13]

Kelajuan yaitu jarak di bagi waktu tempuh, misal sepeda motor bergerak dengan kelajuan $50 \mathrm{~km} / \mathrm{jam}$. Kelajuan tidak bergantung pada arah sehingga kelajuan besaran skalar dan selalu bernilai positif. Alat untuk mengukur kelajuan pada kendaraan disebut spidometer. Kecepatan merupakan kelajuan yang mempunyai arah. Misal sepeda motor bergerak ke barat dengan kecepatan $40 \mathrm{~km} / \mathrm{jam}$. Kecepatan bergantung pada arah sehingga kecepatan termasuk besaran vektor. Dengan demikian, kecepatan dapat bernilai positif atau negatif [13].

Kelajuan rata-rata sebagai hasil bagi jarak total yang ditempuh dengan waktu tempuhnya.

$$
v=\frac{s}{t}
$$

Oleh karena jarak merupakan besaran skalar maka kelajuan ratarata juga besaran skalar. Jadi, kelajuan rata-rata tidak bergantung pada arah. Kecepatan rata-rata adalah hasil bagi anatara perpindahan dan selang waktunya.

$$
\vec{v}=\frac{\Delta \vec{s}}{\Delta t}
$$

Penulis [13] menunjukkan, kelajuan sesaat adalah kelajuan pada suatu saat tertentu (sangat pendek). Demikian juga kecepatan sesaat adalah kecepatan pada suatu saat tertentu (sesaat). Kecepatan sesaat untuk $\Delta t$ yang sangat kecil dirumuskan sebagai berikut.

$$
\vec{v}=\lim _{\Delta t \rightarrow 0} \frac{\Delta \vec{s}}{\Delta t}
$$




\section{JIP Fo}

\section{MetODE}

Metode penelitian dalam penelitian ini adalah metode deskriptif sederhana. Jenis penelitian yang digunakan adalah analisis isi. Dalam analisis isi, tujuan target inferensi harus dinyatakan secara jelas, masalah apa yang akan diinginkan diketahui oleh analisis. Adapun tujuan analisis isi dalam penelitian ini untuk menyajikan fakta berupa miskonsepsi tentang dinamika gerak pada buku ajar fisika SMA kelas X.

Populasi dalam penelitian ini adalah buku-buku ajar fisika SMA kelas $\mathrm{X}$ yang digunakan di beberapa sekolah di kota Singkawang dan kabupaten Bengkayang. Sampel penelitian berupa buku-buku ajar fisika SMA yang dipilih secara Sampel dalam penelitian ini adalah buku-buku ajar fisika SMA yang dipilih secara purposive sampling. Yaitu teknik pengambilan sampel secara sengaja. Maksudnya, ditentukan sendiri sampel yang diambil karena ada pertimbangan tertentu. Subtansisubtansi atau sub-sub bahasan dalam buku-buku sampel yang dipilih dan digunakan memiliki kesamaan yang kemudian memudahkan untuk diteliti ketika dibandingkan dan mendapatkan data yang akurat. Adapun buku ajar fisika SMA yang digunakan sebagai sampel penelitian, yaitu: (1) Fisika untuk SMA/MA kelas X, karangan Kamajaya dengan penerbit Grafindo Media Pratama Tahun 2007 (MA. Ushuluddin Singkawang), (2) Fisika untuk SMA/MA kelas X, karangan Supiyanto dengan penerbit Phibeta Aneka Gama Tahun 2007 ( SMA Negeri 1 Samalantan), dan (3) Fisika untuk SMA/MA kelas X, karangan Rinawan Abadi dan Syarifah Isnaini dengan penerbit Intan Pariwara Tahun 2012 (SMA Negeri 6 Singkawang). Data penelitian berupa aspek-aspek miskonsepsi pada buku ajar yang diteliti meliputi aspek penjelasan konsep, penulisan dan penyajian gambar.

Penulis [14] menunjukkan, rangkaian desain analisis isi meliputi beberapa langkah berikut ini: (1) pembentukan data, (2) reduksi data, (3) penyajian data, (4) penarikan kesimpulan, dan (5) analisis data. Dalam pembentukan data, peneliti terlebih dahulu merumuskan dengan tepat apa yang ingin diteliti dan semua tindakan harus didasarkan pada tujuan penelitian. Pembentukan data dapat diambil dalam bentuk unitisasi, sampling, dan pencatatan. Reduksi data berarti merangkum, memilih hal-hal yang pokok, memfokuskan halhal yang penting, mencari tema dan polanya dan membuang yang tidak perlu. Dalam hal ini, data yang akan direduksi dalam buku ajar berhubungan dengan aspek-aspek miskonsepsi.

Pada tahap penyajian data, data-data dalam buku ajar yang telah dikumpulkan kemudian dibandingkan dengan data-data yang diambil pada buku acuan (buku teks fisika universitas). Data-data yang telah diperoleh dalam buku ajar kemudian dianalisis dengan melakukan studi pustaka. Konsep yang benar hasil studi pustaka diambil pada buku teks fisika universitas dan digunakan sebagai acuan dalam menganalisis miskonsepsi pada buku ajar. Penarikan kesimpulan diambil dengan memutuskan bahwa data dalam buku ajar mengalami miskonsepsi jika tidak sesuai dengan data pada buku acuan. Jika data dalam buku ajar sesuai dengan buku acuan, maka dianggap tidak mengalami miskonsepsi. Data-data dalam buku ajar yang mengalami miskonsepsi kemudian dianalisis dengan memberikan alasan penyebab data tersebut mengalami miskonsepsi dan juga memberikan saran agar data-data pada buku ajar tidak berpotensi mengalami miskonsepsi.

\section{HASIL DAN PEMBAHASAN}

\section{A. Hasil Penelitian}

Data yang dianalisis dalam buku ajar fisika SMA berupa miskonsepsi meliputi aspek penjelasan konsep, penulisan (rumus, simbol dan satuan) dan penyajian gambar. Miskonsepsi pada buku ajar dapat diidentifikasi dengan melakukan studi pustaka. Konsep-konsep benar hasil studi pustaka digunakan sebagai acuan dalam mengidentifikasi miskonsepsi pada buku ajar fisika SMA. Konsep-konsep tersebut diambil dari buku teks fisika universitas, yaitu buku Giancoli (2001), Halliday, Resnick \& Walker (2001), Tipler (1998), Young \& Freedman (2002), Ganijanti Aby Sarojo (2013), Sears. Zemansky (1994). Dalam menganalisis suatu data, jika pada salah satu buku ajar data yang akan diteliti tidak ada, maka buku ajar tersebut dianggap tidak mengalami miskonsepsi pada data tersebut.

Miskonsepsi pada aspek penjelasan konsep pada buku ajar adalah kesalahan konsep-konsep pada buku ajar berupa penjelasan yang kurang jelas, tidak tepat, terlalu matematis, pengggunaan bahasa yang kurang tepat maupun tidak sesuai dengan konsep-konsep yang ada pada buku acuan (buku fisika universitas). Adapun konsep-konsep yang diteliti antara lain konsep gerak lurus, jarak dan perpindahan, kelajuan dan kecepatan, kelajuan rata-rata dan kecepatan rata-rata, kelajuan sesaat dan kecepatan sesaat, percepatan, percepatan rata-rata, percepatan sesaat, gerak lurus beraturan dan gerak lurus berubah beraturan.

Miskonsepsi pada aspek penulisan meliputi tiga bagian yaitu, aspek penulisan rumus, simbol dan satuan. Rumus adalah kesalahan penulisan rumus yang terdapat pada buku ajar dan tidak sesuai dengan penulisan rumus pada buku acuan tanpa keterangan yang jelas. Adapun rumus yang diteliti antara lain perpindahan, kelajuan rata-rata dan kecepatan ratarata, kelajuan sesaat dan kecepatan sesaat, percepatan rata-rata, percepatan sesaat, gerak lurus beraturan (hubungan antara jarak, kelajuan (nilai kecepatan benda), dan selang waktu), dan gerak lurus berubah beraturan (hubungan antara kecepatan dan percepatan, hubungan antara perpindahan dan percepatan serta waktu, hubungan antara perpindahan dan kecepatan serta percepatan).

Miskonsepsi pada aspek penulisan simbol adalah kesalahan penulisan simbol yang terdapat pada buku ajar dan tidak sesuai dengan penulisan simbol pada buku acuan tanpa keterangan yang jelas. Adapun satuan yang diteliti antara lain kedudukan atau posisi,waktu, jarak, perpindahan, kecepatan awal dan akhir, kelajuan rata-rata dan kecepatan rata-rata, kelajuan sesaat dan kecepatan sesaat, percepatan, percepatan rata-rata, dan percepatan sesaat.

Miskonsepsi pada aspek penulisan satuan adalah kesalahan penulisan satuan pada buku ajar yang tidak sesuai dengan penulisan simbol pada buku acuan maupun tidak sesuai dengan standar Sistem Internasional (SI) tanpa keterangan yang jelas. Adapun satuan yang diteliti antara lain kedudukan atau posisi, waktu, jarak, perpindahan, kelajuan dan kecepatan, 
kelajuan rata-rata dan kecepatan rata-rata, kelajuan sesaat dan kecepatan sesaat, percepatan, dan percepatan rata-rata.

Miskonsepsi pada aspek penyajian gambar adalah kesalahan penyajian gambar pada buku ajar, yaitu ketidaksesuian antara penjelasan konsep pada penyajian gambar. Adapun gambar yang diteliti antara lain perpindahan, kelajuan dan kecepatan, kelajuan rata-rata dan kecepatan ratarata, kelajuan sesaat dan kecepatan sesaat, percepatan, gerak lurus beraturan, dan gerak lurus berubah beraturan.

Analisis data dilakukan pada masing-masing aspek miskonsepsi dalam buku ajar fisika SMA yang meliputi aspek penjelasan konsep, penulisan (rumus, simbol, dan satuan), dan penyajian gambar pada materi kinematika gerak lurus. Hasil analisis berupa data-data dalam buku ajar yang mengalami miskonsepsi dan besarnya persentase miskonsepsi pada masing-masing aspek disajikan dalam Tabel 1 sebagai berikut.

TABEL I

REKAPITULASI BENTUK-BENTUK MisKONSEPSi BUKU AJAR FISIKA SMA KELAS X PADA POKOK BAHASAN KINEMATIKA GERAK LURUS

\begin{tabular}{|c|c|c|c|c|}
\hline \multirow{2}{*}{$\begin{array}{l}\text { No } \\
1\end{array}$} & \multirow{2}{*}{$\begin{array}{l}\text { Konsep } \\
\text { Penjelasan } \\
\text { Konsep }\end{array}$} & \multicolumn{3}{|c|}{ Miskonsepsi Buku Ajar } \\
\hline & & IP & PAG & GMP \\
\hline & Persentase & $20 \%$ & $10 \%$ & $20 \%$ \\
\hline 2 & $\begin{array}{l}\text { Penulisan } \\
\text { Rumus }\end{array}$ & IP & PAG & GMP \\
\hline & 'Persentase & $66,67 \%$ & $22,22 \%$ & $44,44 \%$ \\
\hline 3 & $\begin{array}{l}\text { Penulisan } \\
\text { Simbol }\end{array}$ & IP & PAG & GMP \\
\hline & Persentase & $40 \%$ & $10 \%$ & $10 \%$ \\
\hline 4 & $\begin{array}{l}\text { Penulisan } \\
\text { Satuan }\end{array}$ & IP & PAG & GMP \\
\hline & Persentase & $0 \%$ & $0 \%$ & $0 \%$ \\
\hline 5 & $\begin{array}{l}\text { Penyajian } \\
\text { Gambar }\end{array}$ & IP & PAG & GMP \\
\hline & Persentase & $20 \%$ & $20 \%$ & $0 \%$ \\
\hline
\end{tabular}

\section{B. Pembahasan}

Pada aspek penjelasan konsep dari ketiga buku ajar yang telah dianalisis, ada sedikit miskonsepsi yang terdapat pada buku ajar tersebut. Pada buku ajar Intan Pariwara dan Grafindo Media Pratama hanya terdapat dua konsep yang miskonsepsi. Kedua miskonsepsi yang teridentifikasi berupa penjelasan konsep mengenai kelajuan dan kecepatan serta kelajuan rata-rata dan kecepatan rata-rata yang terdapat pada buku ajar Intan Pariwara. Miskonsepsi lainnya berupa penjelasan konsep mengenai kelajuan rata-rata dan kecepatan rata-rata serta percepatan sesaat pada buku ajar Grafindo Media Pratama. Untuk buku ajar Phibeta Aneka Gama, terdapat satu miskonsepsi pada penjelasan konsep kelajuan rata-rata dan kecepatan rata-rata.

Pada aspek penulisan rumus dari ketiga buku ajar, rumusrumus yang diteliti melalui analisis yang telah dilakukan, sedikit banyak mengalami miskonsepsi. Ada beberapa penulisan rumus yang benar dari ketiga buku ajar tersebut. Buku ajar Intan Pariwara, penulisan rumus yang benar terdapat pada rumus perpindahan, percepatan sesaat, dan gerak lurus beratutan. Sedangkan buku ajar Phibeta Aneka
Gama, penulisan rumus yang tidak benar terdapat pada rumus kelajuan sesaat dan kecepatan sesaat dan Gerak lurus berubah beraturan (hubungan antara perpindahan dan kecepatan serta percepatan). Untuk buku ajar Grafindo Media Pratama, penulisan rumus yang benar terdapat pada rumus perpindahan, kelajuan rata-rata dankecepatan rata-rata, kelajuan sesaat dan kecepatan sesaat, percepatan rata-rata dan gerak lurus beraturan.

Miskonsepsi pada aspek penulisan simbol tidak telalu banyak terdapat pada ketiga buku ajar. Hanya ada beberapa penulisan simbol yang salah dari ketiga buku ajar tersebut. Buku ajar Intan Pariwara, penulisan simbol yang salah berupa simbol kecepatan awaldan akhir, kelajuan rata-rata dan kecepatan rata-rata, kelajuan sesaat dan kecepatan sesaat, dan percepatan rata-rata. Sedangkan buku ajar Phibeta Aneka Gama, penulisan simbol yang salah berupa perpindahan. Untuk buku ajar Grafindo Media Pratama, penulisan simbol yang salah berupa perpindahan.

Pada aspek penulisan satuan dari ketiga buku ajar, tidak ada satupun miskonsepsi yang terjadi dalam ketiga buku ajar tersebut. Namun demikian, ada beberapa satuan yang tidak ada dalam buku ajar yang kemudian dianggap tidak mengalami miskonsepsi. Pada buku Ajar Intan Pariwara, satuan yang tidak ada berupa satuan kedudukan atau posisi, kelajuan dan kecepatan, kelajuan sesaat dan kecepatan sesaat, dan percepatan. Sedangkan pada buku ajar Phibeta Aneka Gama, satuan yang tidak ada berupa satuan kelajuan dan kecepatan dan percepatan rata-rata. Dan untuk buku ajar Grafindo Media Pratama, satuan yang tidak ada berupa satuan kelajuan sesaat dan kecepatan sesaat dan percepatan.

Pada aspek penyajian gambar dari ketiga buku, hanya sedikit miksonsepsi yang terdapat dalam buku ajar tersebut. Buku ajar Intan Pariwara, hanya satu gambar yang disajikan mengalami miskonsepsi. Sedangkan buku ajar Phibeta Aneka Gama juga hanya mengalami miskonsepsi pada penyajian gambar perpindahan. Untuk buku ajar Grafindo Media Pratama tidak terdapat miskonsepsi

\section{KESIMPULAN}

Miskonsepsi aspek penjelasan konsep tentang kinematika gerak lurus terdapat pada buku ajar Intan Pariwara, Phibeta Aneka Gama dan Grafindo Media Pratama. Pada buku ajar Intan Pariwara dan Grafindo Media Pratama masing-masing mengalami miskonsepsi dengan persentase $20 \%$, sedangkan untuk buku ajar Phibeta Aneka Gama mengalami miskonsepsi dengan persentase $10 \%$. Pada aspek penjelasan penulisan, miskonsepsi tentang kinematika gerak lurus juga terdapat pada buku ajar Intan Pariwara, Phibeta Aneka Gama, dan Grafindo Media Pratama. Miskonsepsi yang dialami ketiga buku ajar tersebut banyak terjadi pada aspek penulisan rumus dan penulisan simbol. Buku ajar Intan Pariwara mengalami miskonsepsi pada aspek penulisan rumus dengan persentase $66,67 \%$ dan aspek penulisan simbol dengan persentase $40 \%$. Sedangkan buku ajar Phibeta Aneka Gama mengalami miskonsepsi pada aspek penulisan rumus dengan persentase $22,22 \%$ dan aspek penulisan simbol dengan persentase $10 \%$. Untuk buku ajar Grafindo Media Pratama mengalami miskonsepsi pada aspek penulisan rumus dengan persentase 
$44,44 \%$ dan aspek penulisan simbol dengan persentase $10 \%$. Pada aspek penulisan satuan, tidak terdapat miskonsepsi dalam buku ajar Intan Pariwara, Phibeta Aneka Gama, dan Grafindo Media Pratama. Pada aspek penyajian gambar, ada beberapa miskonsepsi pada materi kinematika gerak lurus dalam buku ajar Intan Pariwara dan Phibeta Aneka Gama. Miskonsepsi pada aspek penyajian gambar terdapat pada buku Intan Pariwara dengan persentase 20\%. Pada buku ajar Phibeta Aneka Gama mengalami miskonsepsi aspek penyajian gambar dengan persentase 20\%. Sedangkan buku ajar Grafindo Media Pratama tidak mengalami miskonsepsi aspek penyajian gambar.

\section{UCAPAN TERIMA KASIH}

Penulis mengucapkan terima kasih kepada Drs. H. Andi Mursidi MPA., M.Si selaku ketua STKIP Singkawang yang telah memberikan dukungan materil dan moral kepada penulis. Tidak lupa juga penulis mengucapkan terima kasih kepada Andika Kusuma Wijaya, M.Pd.Si selaku penulis kedua dan Intan Kusumwati, M. Pd selaku penulis ketiga yang banyak membantu dalam penyelesaian tulisan ini sehingga dapat dipublikasikan di berkala ilmiah STKIP Singkawang.

\section{DAFTAR PUSTAKA}

[1] Moh. Ali, Ilmu dan Aplikasi Pendidikan Bagian 1 Ilmu Pendidikan Teoritis, Bandung: IMTIMA, 2007.

[2] Nurul Fitrianingrum, Widha Sunarno, dan Dewanto Harjunowibowo, Analisis Miskonsepsi Gerak Melingkar pada Buku Sekolah Elektronik (BSE) Fisika Sma Kelas $\mathrm{X}$ Semester I. Jurnal Pendidikan Fisika. Surakarta: Universitas Sebelas Maret, 2013, vol. 1.

[3] Andi Desy Yuliana Mukti, Trustho Raharjo, dan Edy Wiyono, Identifikasi Miskonsepsi dalam Buku Ajar Fisika SMA Kelas X Semester Gasal, Jurnal Materi dan Pembelajaran Fisika. Springer, 2012, vol. 1.

[4] P. Suparno, Miskonsepsi \& Perubahan Konsep dalam pendidikan Fisika, Jakarta: Grasindo 2005.

[5] E. O. Cobanoglu, Sahim, dan Sahim, B, Underlining the Problem In Biology Textbook for 10th Grades In High School Education Using the Suggestions of Practicing Teachers, Journal of Turkish Science Education. 2009, vol. 6.

[6] Nur Khoiri, N. Hindarto, Suhaldi, Pengembangan Perangkat Pembelajaran Fisika Berbasis Life Skill untuk Meningkatkan Minat Kewirausahaan Siswa, Jurnal Pendidikan Indonesia. Semarang: Universitas Negeri Semarang (Unnes), 2011, vol. 7.

[7] Agus Pujianto, Analisis Konsepsi Siswa Pada Konsep Kinematika Gerak Lurus, Jurnal pendidikan Fisika Tadulako (JPFT). Tadulako: Prodi Pendidikan Fisika FKIP Universitas Tadulako, 2011, vol. 1.

[8] Young Hough D. Freedman Roger A., Fisika Universitas edisi kesepuluh Jilid I (Terjemahan), Jakarta: Erlangga, 2002.

[9] Douglas C. Giancoli, Fisika Edisi kelima (diterjemahkan oleh Yuhilza Hanum) (Terjemahan). Jakarta: Erlangga, 2001.
[10] Halliday D, R. Resnick, dan J. Walker, Dasar-Dasar Fisika Versi Diperluas Jilid I (Editor: Syarifudin, Mike Damayanti, dan Yayan Wulandari) (Terjemahan). Surabaya: Binarupa Aksara, 2001.

[11] P. A. Tipler, Fisika Untuk Sains dan Teknik Jilid I (Terjemahan). Jakarta: Erlangga, 1998.

[12] G. A. Sarojo, Seri Fisika Dasar Mekanika edisi 5. Jakarta: Salemba Teknika, 2013.

[13] R. Abadi, Syafiah Isnaini., Syafiah Isnaini. Klaten: Intan Pariwara, 2012.

[14] Klaus Krippendorff, Analisis Isi:Pengantar Teori dan Metodenya. Jakarta: Rajawali Press, 1991. 